\title{
Triaxial Compression on Semi-solid Alloys
}

\author{
FATIN N. ALTUHAFI, CATHERINE O'SULLIVAN, PETER SAMMONDS, \\ TE-CHENG SU, and CHRISTOPHER M. GOURLAY
}

\begin{abstract}
Multi-axial compression of the mushy zone occurs in various pressurized casting processes. Here, we present a drained triaxial compression apparatus for semi-solid alloys that allow liquid to be drawn into or expelled from the sample in response to isotropic or triaxial compression. The rig is used to measure the pressure-dependent flow stress and volumetric response during isothermal triaxial compression of globular semi-solid Al- 15 wt pet $\mathrm{Cu}$ at 70 to 85 vol pet solid. Analysis of the stress paths and the stress-volume data show that the combination of the solid fraction and mean effective pressure determines whether the material undergoes shear-induced dilation or contraction. The results are compared with the critical state soil mechanics (CSSM) framework and the similarities and differences in behavior between equiaxed semi-solid alloys and soils are discussed.
\end{abstract}

https://doi.org/10.1007/s11661-021-06213-9

(C) Crown 2021

\section{INTRODUCTION}

PRESSURIZED metal casting processes (e.g., high-pressure die casting and squeeze casting) and processes that combine deformation processing with solidification processing (e.g., twin-roll casting and semi-solid forging) have the potential to be the most cost-effective and least environmentally damaging metal processing routes. Each of these processes applies multi-axial compression to the mushy zone, and the rheological response determines how the semi-solid material deforms in the die and/or how defects such as deformation-induced macrosegregation occur. To optimize these processes, it is necessary to have a predictive understanding of the pressure-dependent rheology of semi-solid alloys at solid fractions where a solid network is present, for semi-solid morphologies ranging from equiaxed dendritic to globular (Figure 1).

FATIN N. ALTUHAFI is with the Department of Civil, Environmental and Geomatic Engineering, University College London, London WC1E 6BT, UK. Contact e-mail: f.altuhafi@ucl.ac.uk CATHERINE O'SULLIVAN is with the Department of Civil and Environmental Engineering, Imperial College London, London SW7 2AZ, UK. PETER SAMMONDS is with the Rock and Ice Physics Laboratory, Department of Earth Sciences, Institute for Risk \& Disaster Reduction, University College London, London WC1E 6BT, UK. TE-CHENG SU is with the Department of Materials Science and Engineering, National Taiwan University, Taipei 10617, Taiwan. CHRISTOPHER M. GOURLAY is with the Department of Materials, Imperial College London, London SW7 2AZ UK.

Manuscript submitted November 13, 2020; accepted February 14, 2021.

Article published online March 21, 2021
Past research has shown that compressive deformation of semi-solid alloys can lead to different types of behavior. The solid network can be compressed expelling liquid ${ }^{[1-3]}$ as a consequence both of grain rearrangement and grain deformation. The network can also exhibit Reynolds' dilatancy ${ }^{[4]}$ (also known as shear-induced dilation) where the grains push or lever one another apart as they begin to rearrange (translate and rotate) under load and extra liquid is drawn into the expanding interstices between grains. ${ }^{[5-8]}$ Since the solid network can contract or dilate, causing liquid to be expelled or drawn-in, volumetric strains can be important during the compressive deformation of semi-solid alloys. As the solid fraction increases within the solid network (Figure 1), deformation of the grains is thought to become an increasing component of deformation and constitutive models often treat the rheology as viscoplastic deformation of a strain-rate-sensitive partially cohesive porous solid skeleton saturated with liquid (e.g., ${ }^{[3,9]}$ ). There is also a complex coupling between the rearrangement and/or deformation of the solid and flow of the liquid within the low permeability mush. ${ }^{[10,11]}$

Good constitutive models that capture such volumetric strains and the pressure-dependent rheology, and link between the low solid fraction suspension regime and high solid fraction regime remain a significant challenge, and this area is under continuous development. ${ }^{[9,12]}$ The tests required to support the development of such models are non-trivial, and one approach to expedite modeling capabilities is to look for analogue/ similar materials and assess whether models or general frameworks that describe their behavior under different conditions can be used or adapted for use with semi-solid metals. 


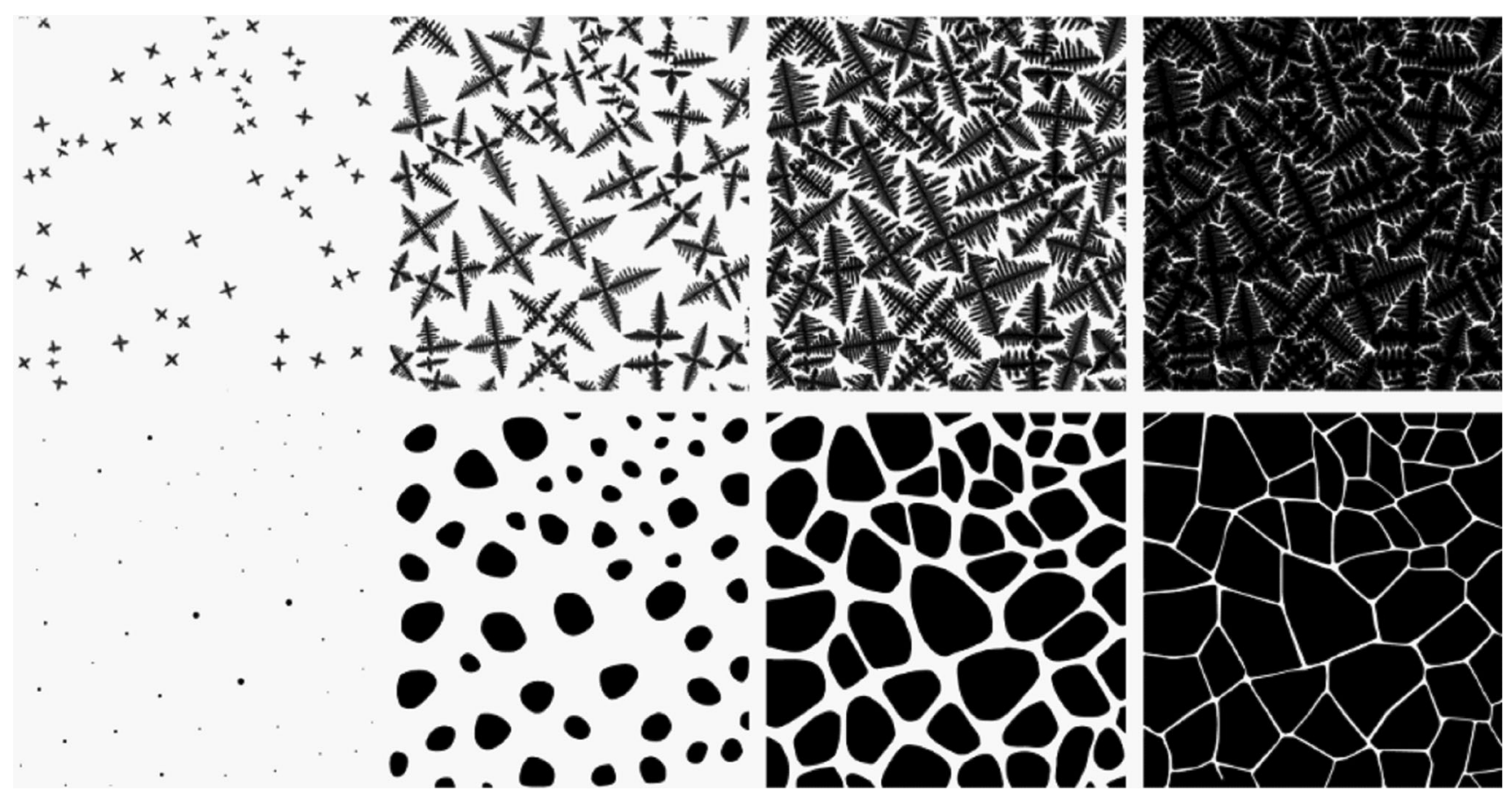

Fig. 1-Semi-solid microstructure development in a uniform thermal field. Top: equiaxed dendritic solidification. Bottom: globular grains during solidification or remelting.

In previous publications, some similarities in the response to loading have been noted between semi-solid alloys and granular soils, ${ }^{[2,5,13]}$ and a range of mechanical testing procedures similar to those developed to study soil mechanics have been applied to semi-solid alloys, including vane tests, ${ }^{[14,15]}$ direct shear tests, ${ }^{[16,17]}$ confined uniaxial filtration, ${ }^{[2,3]}$ and triaxial compression. ${ }^{[18-20]}$ However, while these tests are similar to tests procedures used in soil mechanics, unfortunately, they lack some important features necessary to enable a comprehensive understanding of the material behavior. For example, while the direct shear test devices used in soil mechanics can apply a normal stress and measure volumetric strains, these features have been omitted in direct shear testing on semi-solid alloys. ${ }^{[16,17]}$ The most common approach to measuring semi-solid deformation has been unconfined compression (i.e., parallel plate compression), ${ }^{[1,11,21-28]}$ but these tests usually lack a method to link the volumetric behavior to the applied stress regime. In one study that did measure volume changes during parallel plate compression, ${ }^{[29]}$ it was found that volumetric strains can be an important part of the semi-solid mechanical response.

Triaxial compression tests on semi-solid alloys where the sample is subjected to controlled pressure are limited in the literature. Some pioneering triaxial compression tests on semi-solid alloys have been carried out by Martin et al..$^{[2,18]}$ and Nguyen et al..$^{[19,20]}$ on semi-solid $\mathrm{Sn}-15$ wt pct $\mathrm{Pb}$. However, these tests had no means of continuous measurement of the sample interstitial liquid change during tests. Using this configuration, sample contraction could be studied by the expulsion of liquid, however, it was impossible to quantify or detect any increase in sample volume by liquid in-flow during shear-induced dilation.

This paper describes the design and development of a novel triaxial setting for semi-solid alloy testing. The design aim was to enable acquisition of data which link the volumetric deformation behavior with the applied stress regime in a semi-solid alloy at a range of confining pressures. The resultant rig allows measurement of specimen volumetric change due to either the in-flow or expulsion of liquid from the sample. Specimens of globular semi-solid Al-15 wt pet $\mathrm{Cu}$ alloy samples were tested to obtain such data and to evaluate the potential use of soil mechanics deformation theories for mushy zone behavior interpretation.

\section{METHODS}

\section{A. Triaxial Testing Requirements}

The testing apparatus developed in this research is similar, in principle, to the triaxial testing apparatus proposed by Bishop, ${ }^{[30]}$ illustrated in Figure 2(a), that is widely used in mechanical testing of soil (both in research and engineering practice) to advance understanding and determine appropriate parameters for use in engineering design and analysis. Adaptations to the conventional apparatus configuration were required to allow testing of semi-solid alloy samples at high temperatures. In this section, an overview of the conventional soil mechanics triaxial apparatus is presented and compared to a triaxial cell previously used for semi-solid alloy testing ${ }^{[18-20]}$ before a description of the new designed cell is presented. 

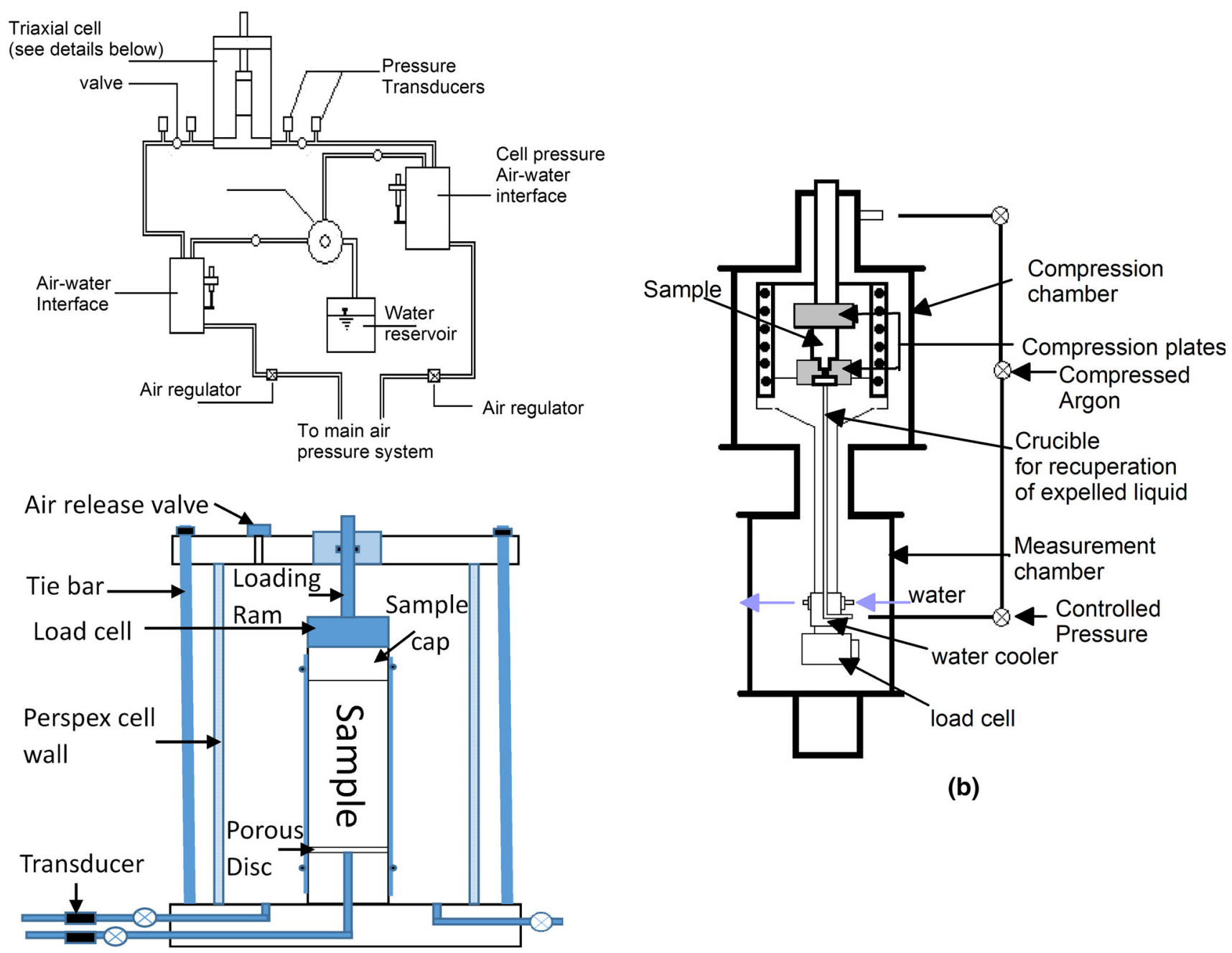

(b)

(a)

Fig. 2-(a) Schematic diagram of conventional triaxial cell with the full set-up. (b) Triaxial testing setting used by Nguyen et al. ${ }^{[20]}$ and Martin et al. ${ }^{[2]}$. After Nguyen et al. ${ }^{[20]}$

The soil mechanics triaxial cell comprises of a pressure vessel/cell which accommodates a cylindrical sample with a height-diameter ratio that is usually $2: 1$. The cell can be pressurized to subject the sample to three-dimensional homogeneous pressure (hydrostatic pressure), and a vertical ram allows a deviator stress to be applied, while monitoring the change in sample volume by measuring the liquid (water in the case of soils) entering or leaving the sample usually with a calibrated pressure-volume controller or volume gauge.

In liquid-saturated samples, the stress must be adjusted to account for buoyancy effects; the principle of effective stress states that the strength and deformation characteristics depend on the effective stress tensor $\sigma^{\prime 31]}$ :

$$
\boldsymbol{\sigma}^{\prime}=\boldsymbol{\sigma}_{\mathrm{tot}}-\mathbf{u},
$$

where $\boldsymbol{\sigma}_{\text {tot }}$ is the externally applied total stress tensor and $\mathbf{u}$ is the pressure tensor for the interstitial liquid in between the grains. The symbol "“" is included when stresses are expressed in terms of effective stress. This principle is usually applied to fully saturated samples when all the interstices are completely filled with liquid (no air/gas present). A significantly different meaning of the 'effective stress' is witnessed in Eq. [1] compared with the same term in solid mechanics where it usually refers to the von Mises stress (a scalar).

To allow free deformation, samples are encased within thin flexible membrane and uniform stress termed a "confining" or "cell" pressure $\left(\sigma_{\text {cell }}^{\prime}\right)$ is applied to the sample sides. Shearing is typically performed by applying a vertical deviator stress $q$ to an initially isotropically loaded sample so that $\sigma_{\text {cell }}^{\prime}$ equals the minor and intermediate principal stresses, i.e., $\sigma_{\text {cell }}^{\prime}=\sigma_{3}^{\prime}=\sigma_{2}^{\prime}$, and the major principal stress (vertical stress) is $\sigma_{\mathrm{v}}^{\prime}=q+\sigma_{\text {cell }}^{\prime}$. The mean effective pressure $p^{\prime}$ is as follows:

$$
p^{\prime}=\left(\frac{\sigma_{1}^{\prime}+2 \sigma_{\text {cell }}^{\prime}}{3}\right)
$$


The data obtained from a triaxial test can be linked to the Mohr-Coulomb model for material yield, in which the shear stress and mean effective pressure can be related to the deviator stress $q$ and the mean effective pressure $p^{\prime}$, and the angle of shearing resistance of the material $\left(\phi^{\prime}\right)$ at any time during triaxial shear loading can be calculated from the relation ${ }^{[32]}$ :

$$
\sin \left(\phi^{\prime}\right)=\frac{3\left(q / p^{\prime}\right)}{6+\left(q / p^{\prime}\right)} .
$$

Triaxial testing of soil can be performed in either drained or undrained conditions. In this paper, we will focus on drained conditions as it allows full monitoring of volumetric deformation of the sample, relevant to the aim of this research. In drained tests on saturated samples, water can freely flow to and from the void space by providing liquid storage with access to the sample to compensate for volume change of the sample during dilation and to accommodate any excess volume during sample contraction. The volume of the liquid that moves into or out of the sample is accurately monitored to give the change in sample volume and the change in solid fraction (often expressed in terms of a void ratio, $e$, the ratio of the volume of total interstices in the sample to the volume of solid). In a zero porosity semi-solid alloy, $e$ can be defined in terms of solid volume fraction, $g_{\mathrm{s}}$ as follows:

$$
e=\frac{\left(1-g_{\mathrm{s}}\right)}{g_{\mathrm{s}}}
$$

Figures 2(a) and (b) enable a direct comparison between the triaxial testing technique used for soil testing ${ }^{[30]}$ with the triaxial testing apparatus used previously for semi-solid alloy testing ${ }^{[1,3]}$ which enables the application of similar stress regime but lacks any method to detect any increase (dilation) of sample volume as it only monitors the liquid metal expelled by the sample.

\section{B. New Triaxial Testing Apparatus for Semi-solid Alloys}

A schematic diagram of the new apparatus is shown in Figure 3. The test set-up uses pressurized argon gas to apply a controlled confining pressure to a cylindrical sample $24.4 \mathrm{~mm}$ in diameter and $50 \mathrm{~mm}$ in height. The sample comprising the cylindrical alloy, its top ceramic cap (with low thermal conductivity), and a stainless steel mesh placed at the base of the sample are all enclosed in a tight-fitting, thin aluminum jacket (wall thickness 0.3 $\mathrm{mm}$ ) which can easily deform under test conditions considered here. A novel feature of this testing configuration is the liquid-metal reservoir held within a customized thermally conductive ceramic unit situated beneath the sample. This reservoir is connected to the sample through a stainless steel mesh at the base of the sample which allows liquid to flow into and out of the sample to the reservoir while retaining the solid material in the sample. The sieve aperture size of $150 \mu \mathrm{m}$ was selected based on prior observation of the grain sizes

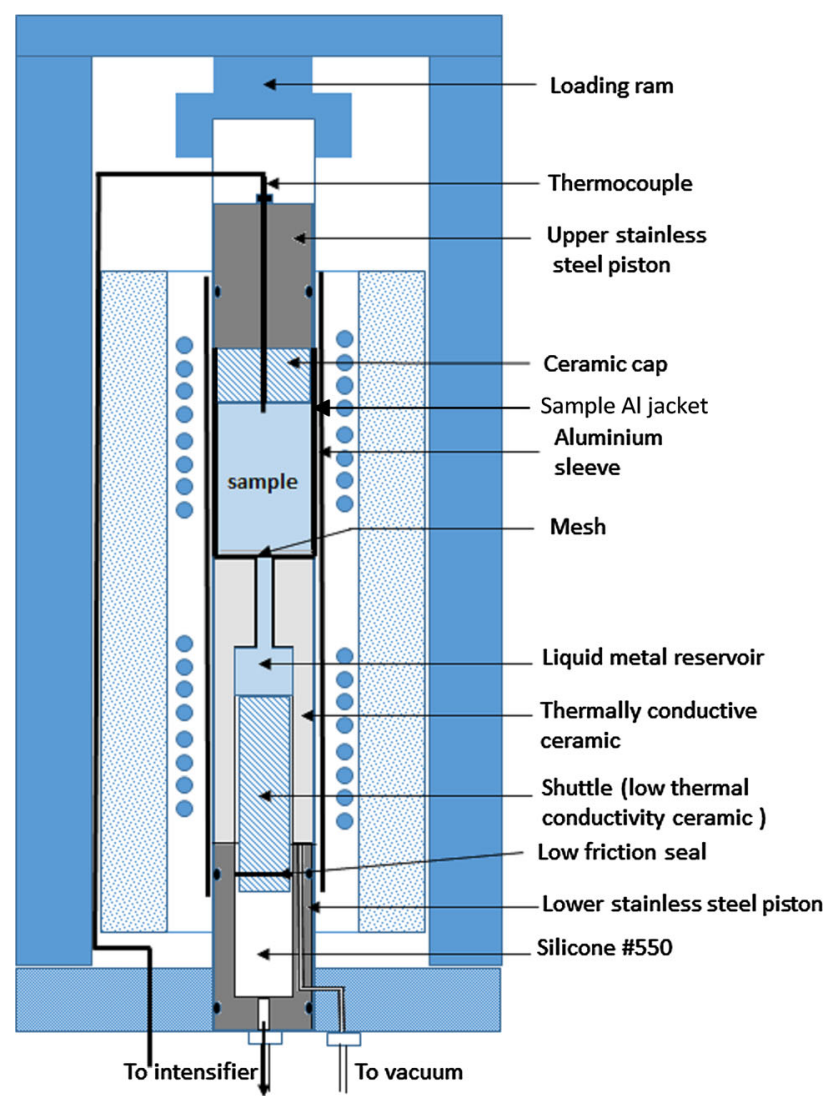

Fig. 3-Schematic diagram of the internal components of the new triaxial cell.

that form in this material at the temperatures considered here; direct observation of the microstructure post testing, as described below, confirmed the grain sizes were $>150 \mu \mathrm{m}$. The reservoir was made to have a sliding ceramic shuttle base and it can accommodate the excess liquid metal that is expelled from the sample, in case of a sample that exhibits a compressive response. The reservoir can also provide liquid metal to the sample in case of sample dilation. In this way, the sample volumetric change can be monitored by the change of the liquid metal entering and leaving the reservoir. The reservoir ceramic shuttle acts as an interface between the liquid metal and the silicone oil which fills the external pipe connection and the $50 \mathrm{~mL}$ intensifier. Any volume change in the liquid metal in the reservoir is reflected in the volume of silicone oil in the intensifier, which was calibrated for volume change measurement. The complete assembly, which includes the jacketed sample with its top cap and the lower reservoir, is isolated from the surrounding pressurized gas in the rig with a second long thin-walled aluminum tube (thickness $=0.3 \mathrm{~mm}$ ) which extends to the upper stainless steel piston at the top, and to the lower stainless steel piston at the bottom and sealed with two sets of O-rings at each end (Figure 3).

The deviator load is applied by the axial ram with a displacement-controlled actuator system and is measured with a specifically designed $20 \mathrm{kN}$ capacity load cell with minimum drift at higher temperatures. Sample 
heating is achieved by the means of two heating elements and two Eurotherm temperature controllers, while the temperature of the sample is monitored using a K-type thermocouple which is placed around 3 to $5 \mathrm{~mm}$ deep at the middle-top of the sample. Another two thermocouples are placed on the external wall of the sample assembly jacket to monitor the temperature of the jacket during testing.

After installing the sample assembly in the rig, the confining pressure is applied and the heating stage is commenced. During the heating stage, the sample assembly is kept open to atmosphere to avoid any air pressure building up in the sample, and the valve to the oil-filled intensifier is kept open to allow any thermal expansion of reservoir material, which is in its solid state at this stage, without exerting excessive thermal pressure on the system. After stabilization, the sample assembly is evacuated of air to maintain an air-free system. Then the shearing stage is commenced by applying controlled axial load. Using this method, the pressure in the interstitial liquid $(u)$ and liquid metal in the reservoir is kept zero during the test.

At the end of the shearing stage, the sample assembly is left in the pressurized rig to cool down with the valve to the intensifier closed. The sample assembly is then retrieved and post-test characterization of the sample is carried out.

\section{Tested Material and Test Details}

Al-15 wt pct $\mathrm{Cu}$ samples with a globular morphology were used. The microstructure was generated by heat treating the cast alloy in the semi-solid state at $553 \pm 1$ ${ }^{\circ} \mathrm{C}$ (corresponding to $\sim 5 \pm 1{ }^{\circ} \mathrm{C}$ above the eutectic temperature) for 8 days, followed by cooling in air. Samples were then machined to the desired dimensions. The resulting samples had equiaxed globular grains with size of $162 \pm 8 \mu \mathrm{m}$ (using the mean linear intercept method $)^{[9]}$ on six etched micrographs under polarized light. Figure 4 shows a typical anodized micrograph to show the grain morphology. This example was taken after deformation at low confining pressure, but this had little effect on the grain shape. The interstitial eutectic regions (black) were excluded when measuring the particle dimensions. This large-grained globular morphology was selected to generate a relatively stable microstructure that would not coarsen significantly during isothermal triaxial testing.

Aluminum (commercial 1050A) was chosen for the sample jacketing system. This jacketing system comprises two thin tubes. The first tube which encloses only the tested sample and the ceramic top cap is machined to have an inner diameter that is a close fit to the sample. The second outer long jacket encloses the sample and the liquid-metal reservoir components together and provides a seal for the whole sample assembly against the cell pressure (Figure 3). As noted above, both jackets were machined with a wall thickness of 0.3 $\mathrm{mm}$. For the liquid reservoir, an alloy of eutectic

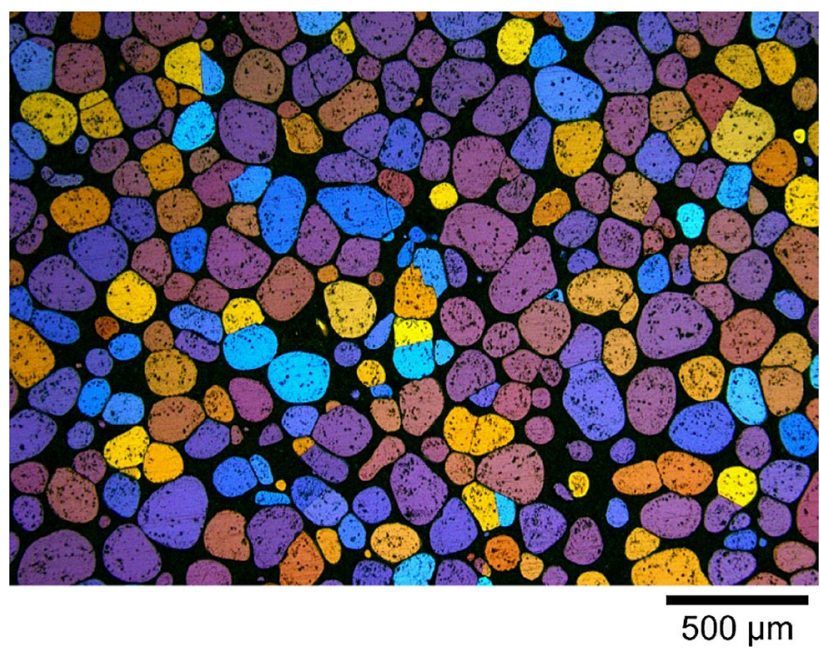

Fig. 4-Typical globular morphology of $300 \mathrm{kPa}-549{ }^{\circ} \mathrm{C}$ sample anodized and viewed under polarized light.

composition (Al-33 wt pet $\mathrm{Cu}$ ) was used. Thus, on reheating to a test temperature in the range 549 to 555 ${ }^{\circ} \mathrm{C}$, the $\mathrm{Al}-33$ wt pet $\mathrm{Cu}$ reservoir material will completely melt and, in the attached $\mathrm{Al}-15$ wt pct $\mathrm{Cu}$ sample, the eutectic will melt leaving a mixture of globular $\alpha$-Al grains of controlled solid fraction and interstitial liquid with composition similar to the liquid in the reservoir. While the near-pure Al jacket will remain solid it will act as a ductile confining membrane.

Three samples were tested at different confining pressures: 300, 600, and $1200 \mathrm{kPa}$. A fourth sample was tested at $300 \mathrm{kPa}$ and then sheared at slightly higher temperature to investigate the effect of temperature, and thus the initial solid fraction, on the sample behavior. Table I gives details of each test and introduces the nomenclature adopted. All tests started with $7.8 \pm 0.05$ $\mathrm{g}$ of $\mathrm{Al}-33 \mathrm{wt}$ pct $\mathrm{Cu}$ in the reservoir which was retrieved and weighed after each test and compared with the measured volumetric data of the test. The mass fraction of solid was calculated from the initial alloy composition and temperature using the Lever rule within ThermoCalc 2019a software with the ALDEMO v.2.0 database, assuming full equilibrium due to the 8-day semi-solid heat treatment. This was converted to a volume fraction using the solid and liquid densities of semi-solid Al-Cu alloys in Reference 33. The solid fraction was adjusted to account for the volumetric change recorded as liquid was expelled or drawn-in during the compression and shearing stages. The final solid fraction deduced by this method was then compared with measurements from image analysis of each (post-test) fully solid sample.

Selected samples were prepared for 'post-mortem' microstructure characterization to assist with the interpretation of the results. Samples were cross-sectioned, ground, and polished using standard metallographic procedures and then anodized for 60 seconds in an $\mathrm{HBF}_{4}$ solution. Reflected light optical microscopy was performed with and without polarized light. 


\section{RESULTS}

\section{A. Isotropic Compression Stage}

All four tests started with a heating stage. The sample was subjected to the designated confining pressure before the heating and stabilization stage. The cell pressure was controlled during the heating stage and shearing stage to stay constant using two automated valves and a controller. It is important to understand the main differences between typical soil mechanics tests and these tests on semi-solid alloys. In mechanical testing of soil, the isotropic compression stage is achieved by applying the confining pressure at a controlled rate, or by applying the full confining pressure to a fully isolated sample (with drainage inhibited) and then monitoring the volumetric change once drainage of the sample is allowed-this point marks the start of the compression stage. In the case of semi-solid alloys, the full confining pressure was applied to the completely solid sample before the start of heating stage. Drainage was permitted during the heating stage to avoid any additional thermal pressure in the system. This means that there is no explicit point at which the heating stage ends and the compression stage starts and here it is assumed that the compression stage starts when the eutectic melts and the alloy reaches its semi-solid state at $548{ }^{\circ} \mathrm{C}$ (Figures 5(a) and b). The change in solid fraction and thus the void ratio of the sample was calculated based on both the change in temperature of the sample and the volumetric change recorded during the compression stage, as the temperature of the sample during this stage was not constant.

Figure 5(b) shows the variation in volumetric strain with time during the isotropic compression stage, the volumetric strain was calculated from the volumetric change in the intensifier and corrected for the expected thermal expansion of the reservoir material. The thermal expansion correction was estimated from a test which was carried out on the same amount of reservoir material (Al-33 wt pet $\mathrm{Cu}$ ) with a dummy ceramic sample to measure the volumetric expansion of the reservoir material only. The isotropic compression stage was around 30 minutes in duration and started at the point when the sample reached its eutectic temperature. In Figure 5(b), a positive volumetric strain is considered to be contractive, and is associated with the expulsion of liquid from the sample.

Liquid flows out of the sample because the interstices decrease in volume due to (i) the grains being pushed into a more tightly packed arrangement and (ii) the viscoplastic deformation of the soft grains into their surrounding interstices. In a soil consisting of hard sand grains, mechanism (i) is dominant. For semi-solid metals, it is expected that both (i) and (ii) occur.

The results in Figure 5(b) indicate that the volumetric strain increases with increasing confining pressure, i.e., during isotropic compression, the volume of liquid expelled is higher when the confining pressure is higher. It is also noted that no clear stable, ultimate volume is reached within the designated isotropic compression time (Figure 5(b)), most likely due to viscoplastic deformation of the solid phase. Referring to Figure 5(b), at a given time, there is a slight difference in the volumetric strains for $300 \mathrm{kPa}-549$ and 300 $\mathrm{kPa}-555$ indicating that $300 \mathrm{kPa}-555$ which was tested at higher temperature (lower solid fraction) was more compressible than $300 \mathrm{kPa}-549$.

\section{B. Shearing Stage}

During shearing, a loading ram displacement rate of $0.002 \mathrm{~mm} / \mathrm{s}$ was used for all tests to avoid build-up of excess interstitial liquid pressure during loading and to allow the liquid metal in the sample interstices to migrate through the sample. Samples were sheared to 12 to $14 \mathrm{pct}$ of axial strain. The sample height after the compression stage, and before shearing commenced, was calculated from the difference in ram displacement readings before starting the test and the start of the shearing stage when the ram is lowered to touch the sample assembly.

The deviator stress $(q)$ recorded during shearing is plotted against axial strain in Figure 6(a). The samples sheared at 600 and $1200 \mathrm{kPa}$ showed an increase in $q$ with axial strain until they reached their steady state, they also exhibited a purely contractive behavior during shear deformation. The contractive volumetric strains in Figure 6(b) were associated with the expulsion liquid from these samples. In contrast, sample $300 \mathrm{kPa}-549$, which was sheared under a lower confining pressure of $300 \mathrm{kPa}$, mobilized a peak in the deviator stress before it reached its steady state (Figure 6(a)). Sample $300 \mathrm{kPa}-549$ deformed with a clear increase in volume (negative volumetric strain) throughout the shearing stage (Figure 6(b)). This dilation corresponds to liquid being drawn into the sample from the liquid reservoir.

Figure 6 also shows the influence of the solid fraction at the start of shear deformation for samples with the same confining pressure. Samples $300 \mathrm{kPa}-555$ and 300 $\mathrm{kPa}-549$ were both sheared under the same confining pressure of $300 \mathrm{kPa}$ but at different temperatures (555 ${ }^{\circ} \mathrm{C}$ and $549^{\circ} \mathrm{C}$ ). Sample $300 \mathrm{kPa}-549$ had $e=0.43$ (solid fraction, $g_{\mathrm{s}}=0.70$, Table I) at the start of shearing and exhibited a net dilative response, so that liquid was drawn into the sample; whereas sample $300 \mathrm{kPa}-555$ which was looser with $e=0.47\left(g_{\mathrm{s}}=0.68\right.$, Table I $)$ at the start of shearing exhibited a net contractive response, and liquid was expelled from the sample.

Microstructure characterization of samples was carried out after the tests by the means of optical micrographs. Images of the central regions of the three samples sheared at temperatures of $549 / 550{ }^{\circ} \mathrm{C}$ are shown in Figure 7. These are segmented images produced using the trainable Weka segmentation plugin ${ }^{[34]}$ in Fiji Image ${ }^{[35]}$; the raw images are given in Supplementary Figure S2. Quantitative analysis of these and similar images gave average final solid fractions of 73 , 78 , and $87 \mathrm{pct}$, which is reasonably consistent with the calculated values from the test data $(68,74$, and 84 pct in Table I) considering that an increase of 3 to $5 \mathrm{vol} p c t$ could be caused by some of the remaining liquid solidifying onto $\alpha$-Al globules on cooling, as well as uncertainties associated with image segmentation, 
Table I. Details of Triaxial Tests on Al-15 Wt Pet Cu

\begin{tabular}{|c|c|c|c|c|c|c|c|}
\hline \multirow[b]{2}{*}{ Test } & \multirow[b]{2}{*}{$\begin{array}{l}\text { Cell Confining } \\
\text { Pressure, } \mathrm{kPa}\end{array}$} & \multirow{2}{*}{$\begin{array}{l}\text { Temperature } \\
\text { at the Start } \\
\text { of Shearing, }{ }^{\circ} \mathrm{C}\end{array}$} & \multicolumn{2}{|c|}{$\begin{array}{l}\text { Estimated Solid Fraction/Void } \\
\text { Ratio at Start of Shearing (After } \\
\text { Compression Stage) }\end{array}$} & \multirow{2}{*}{$\begin{array}{l}\text { Volumetric Strain } \\
\text { During Compression } \\
\text { Stage (Pct) }\end{array}$} & \multicolumn{2}{|c|}{$\begin{array}{c}\text { Final Solid Fraction/ } \\
\text { Void Ratio }\end{array}$} \\
\hline & & & $\begin{array}{l}\text { Solid } \\
\text { Fraction }\end{array}$ & $\begin{array}{l}\text { Void } \\
\text { Ratio }\end{array}$ & & $\begin{array}{l}\text { Solid } \\
\text { Fraction }\end{array}$ & $\begin{array}{l}\text { Void } \\
\text { Ratio }\end{array}$ \\
\hline $300 \mathrm{kPa}-549$ & 300 & 549 & 0.70 & 0.43 & 1.3 & 0.69 & 0.45 \\
\hline $300 \mathrm{kPa}-555$ & 300 & 555 & 0.67 & 0.47 & 2.0 & 0.68 & 0.46 \\
\hline $600 \mathrm{kPa}-550$ & 600 & 550 & 0.71 & 0.40 & 3.1 & 0.74 & 0.35 \\
\hline $1200 \mathrm{kPa}-550$ & 1200 & 550 & 0.75 & 0.32 & 8.5 & 0.84 & 0.19 \\
\hline
\end{tabular}

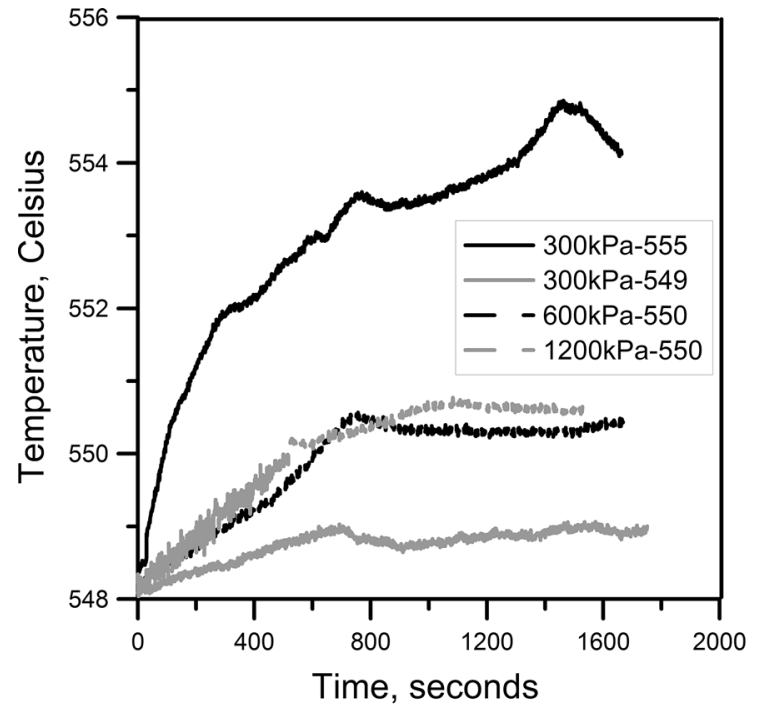

(a)

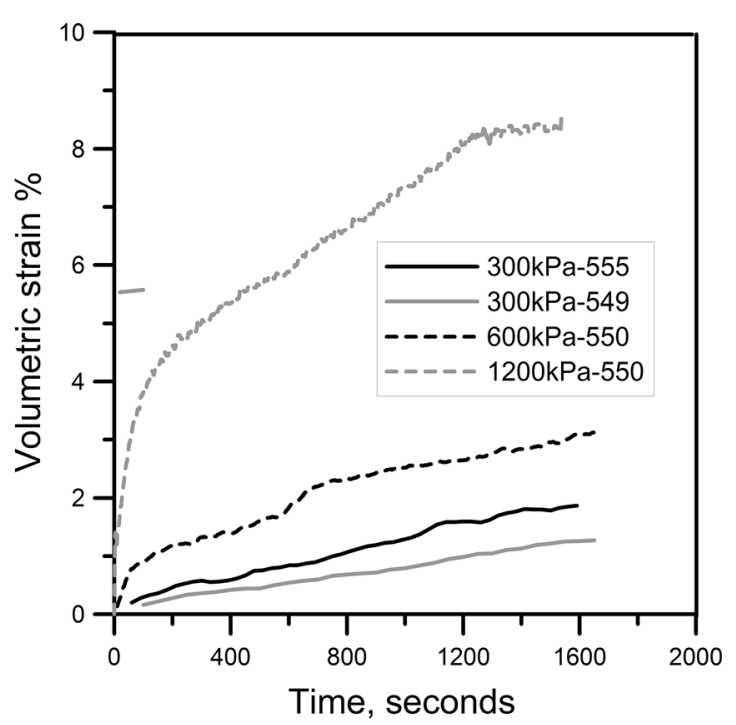

(b)

Fig. 5-Isotropic compression stage (a) sample temperature development with time during compression stage. (b) Volumetric strain development during compression stage.

sample temperature, and composition. The data generated from image analysis support the interpretation that the measured volumetric strains were due to the in-flow and expulsion of liquid from the sample.

$300 \mathrm{kPa}-549$, which gave a macroscopic dilative response in Figure 6, contained microstructural features consistent with dilatancy. For example, Figure 8 shows a band of higher eutectic fraction linked to a bulge in the sample, which will have been a band of higher liquid fraction prior to cooling. This dilatant shear band is similar to shear bands in dense samples of soil undergoing shear-induced dilation, strongly supporting the interpretation that the stress-strain behavior of the 300 kPa-549 sample in Figure 6 is due to shear-induced dilation with liquid being drawn into the sample. At the same time, strain localization presents a significant challenge in the interpretation of granular material behavior in tests including triaxial compression, and the zone of localized deformation can be referred to as a shear band, fault, rupture zone, or simply a failure plane. ${ }^{[36,37]}$ The point of initiation of localized deformation in the sample is often dictated by the location and direction of loading, the geometric configuration, and the boundary conditions.

\section{DISCUSSION}

Since the triaxial compression method used here is similar to that widely used in soil mechanics, it is useful to interpret the measured semi-solid alloy behavior in a soil mechanics framework and to compare the response between the two types of material.

Figure 9 shows the development of the angle of shearing resistance, $\phi$ ' which was calculated using equation (3), against axial strain. An ultimate (end-oftest) $\phi$ ' of around $20^{\circ}$ for all tests can be noted, while sample $300 \mathrm{kPa}-549$ (which underwent shear-induced dilation, Figure 6) exhibited a maximum angle of shearing resistance of about $25^{\circ}$ at around 5 pct axial strain before falling to reach the ultimate value. The maximum (peak) angle of shearing resistance is associated with the point of maximum dilation (Figure 6(b)), similar to past work on shearing of dense soil samples. ${ }^{[32,38]}$ These values of $\phi^{\prime}$ are relatively low compared with values measured for sands (between $27^{\circ}$ and $33^{\circ}$ for ultimate and $35^{\circ}$ to $45^{\circ}$ for maximum angle of shearing $\left.{ }^{[38]}\right)$. However, data for almost spherical relatively smooth glass ballotini samples tested in a soil mechanics triaxial cell give an ultimate $\phi^{\prime}$ of $21^{\circ}$. $^{[39]}$ These 

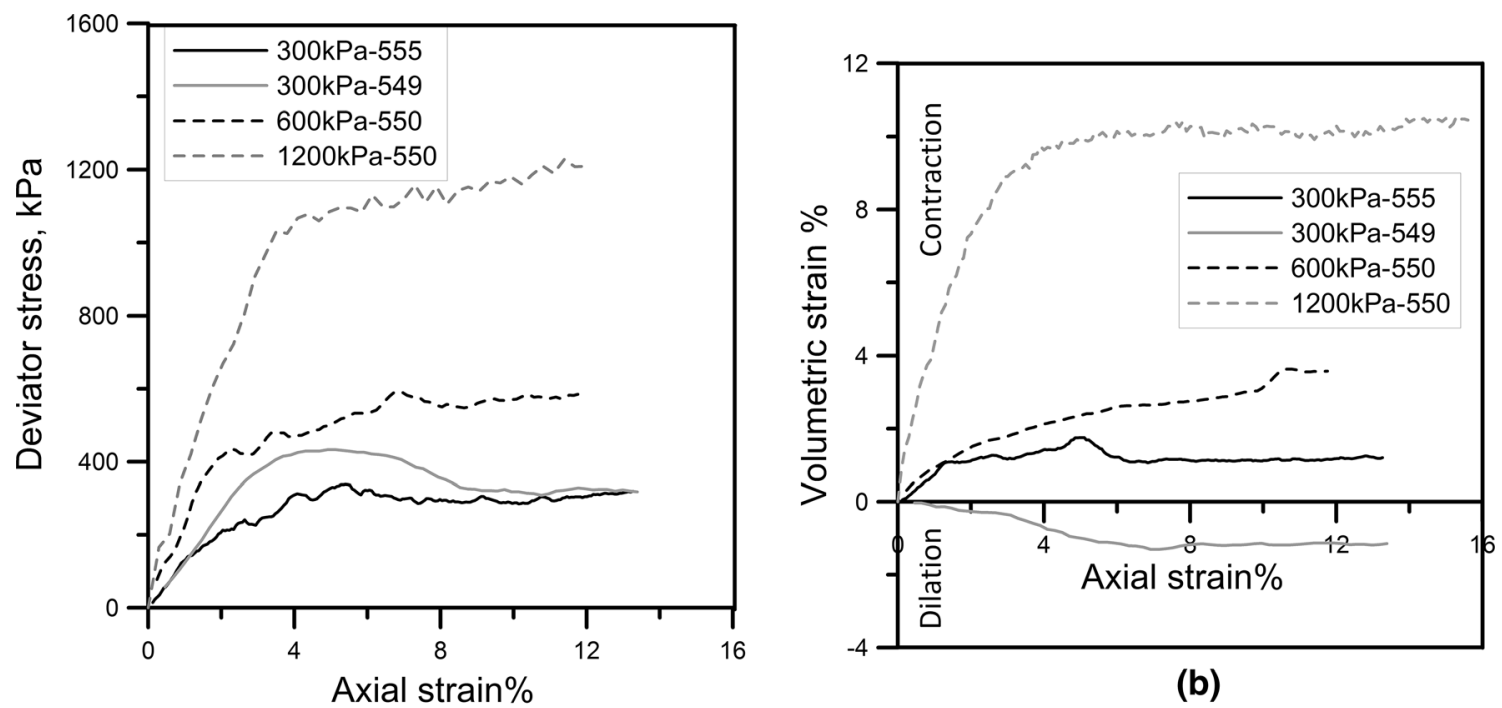

(b)

(a)

Fig. 6- Shearing stage (a) development of deviator stress during shearing stage using the new apparatus. (b) volumetric strain vs. axial strain during shearing stage.

moderately low values of angle of shearing are likely to be because the 8-day semi-solid coarsening used in this work, and further time during semi-solid deformation, produced particularly smooth globules (Figure 4) which will give a low friction coefficient.

Extensive experimental research on both cohesive soils (clays) and cohesionless soils (sands) has established that, irrespective of the initial packing density or stress state, when a given soil is subject to shear deformation, the packing density and stress state can be described by a unique relationship in $e: q: p^{\prime}$ space termed the Critical State Locus or line (CSL). A three-dimensional perspective of the CSL is presented in Figure $10(\mathrm{a}) \cdot{ }^{[40]}$ For simplicity, this relationship is often presented using two (two-dimensional) projections. The first projection maps the CSL onto the $p^{\prime}-q$ plane, as is illustrated in yellow on Figure 10(a). This projection is also presented in Figure 10(c) and it is clear that from this perspective the CSL plots as a straight line. The second projection maps the CSL onto the $e-p$ ' plane which is illustrated in blue on Figure 10(a). It is clear from Figure 10(a) that the projection onto this plane is a curve. However, in soil mechanics, this projection is most often plotted on a semi-logarithmic scale $\left(e-\log p^{\prime}\right)$ as in Figure 10(b); using these axes it appears as a straight line. Figure 10(b) shows also a typical path of isotropic compression of a sample (represented by gray curve), at pressures lower than the material yield pressure when it joins what is called the Isotropic Normal Compression Line (Iso NCL, shown in Figure 10(b) by the broken black line). The Iso NCL is a unique line for the material that all isotropically compressed samples will join eventually when they are compressed beyond their yield pressure. Within the Critical State Soil Mechanics (CSSM) framework, the initial "state" of the material, i.e., the initial values of $e$ and $p^{\prime}$ and their position relative to the CSL for the material under consideration, determines the mechanical behavior. Upon the application of shear loading or deformation, samples with combined e and $p^{\prime}$ values that lie above the CSL, e.g., point A shown in Figures 10(a) and (b), will contract (the grains will move to be closer to each other and liquid will be expelled), producing a denser sample with lower void ratio (higher solid fraction) at a point such as $\mathrm{A}^{\prime}$. When the $e-\ln p^{\prime}$ combination is below the CSL, as is the case for point B (Figures 10(a) and (b)), the sample will dilate during shearing (the solid particles will move apart from each other and liquid will be drawn in) reaching failure or steady state at a point such as B' where the sample has higher void ratio (lower solid fraction); i.e., both $e$ and $p^{\prime}$ determine whether a soil is considered to be loose or dense. The peak (maximum) angle of shearing resistance $\left(\phi_{\text {peak }}^{\prime}\right)$ is mobilized during dilation of dense samples. In granular materials, if two samples of different densities are subject to triaxial shearing at the same effective confining pressure $\left(\sigma_{\text {cell }}^{\prime}=\sigma_{3}^{\prime}\right)$, the denser sample will mobilize a higher $\phi_{\text {peak }}^{\prime}$ (as in Test 300 kPa-549 in Figure 9). The ultimate, or critical state, angle of shearing resistance $\left(\phi_{\mathrm{cs}}^{\prime}\right)$ is mobilized when a steady state is reached at which increasing the strain will not cause any increase in the stress. The value of $\phi_{c s}^{\prime}$ is an intrinsic property of a soil or granular material which does not change with the initial states of different samples that can be created from the given material. In line with this overall trend of material behavior, the data on Figure 9 show that each sample mobilized approximately the same value $\phi^{\prime}=\phi_{\mathrm{cs}}^{\prime}$ of $20^{\circ}$ at the end of testing. 
(a) $300 \mathrm{kPa}-549$

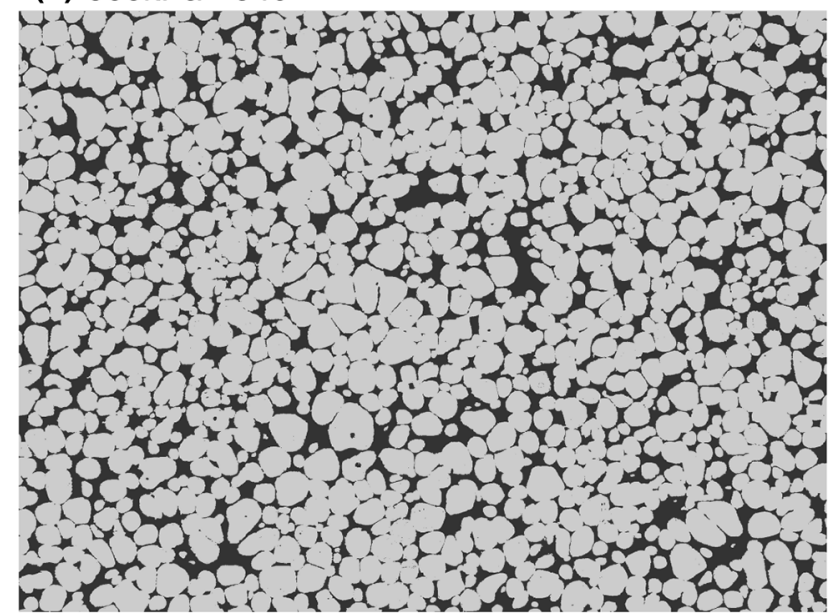

(b) $600 \mathrm{kPa}-550$

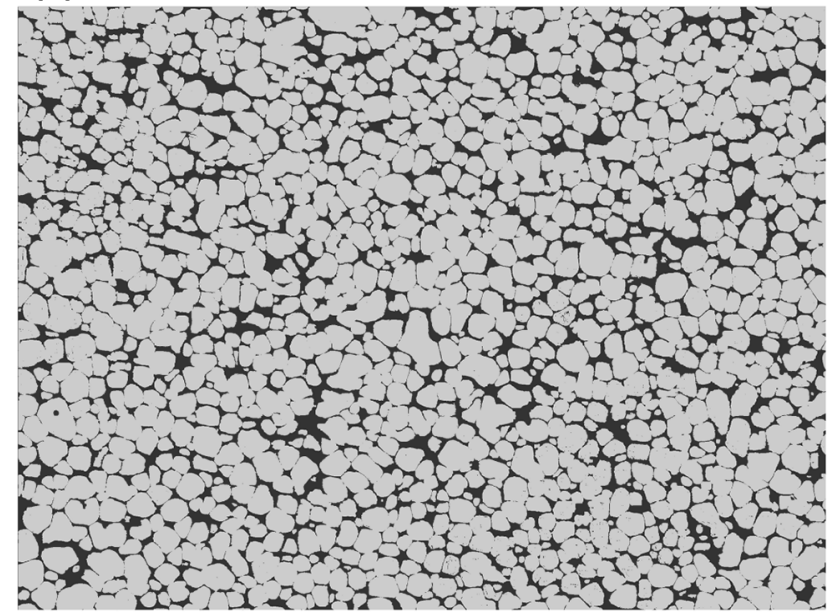

(c) $1200 \mathrm{kPa}-550$

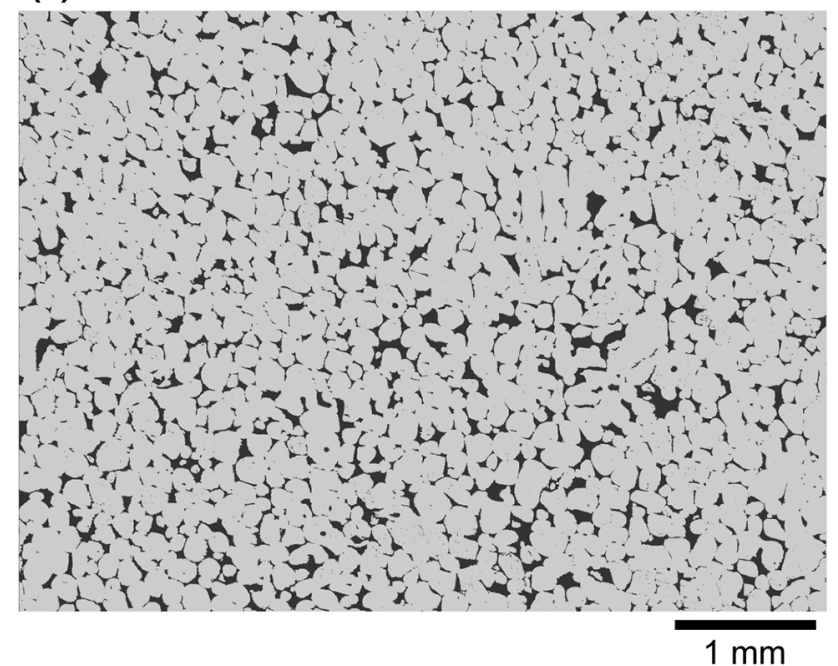

Fig. 7-Segmented micrographs of polished vertical sections. (a) 300 $\mathrm{kPa}-549$, (b) $600 \mathrm{kPa}-550$, and (c) $1200 \mathrm{kPa}-550$ sample. The $\alpha-\mathrm{Al}$ grains are light gray and eutectic (interstitial liquid during tests) are dark gray.

The test series documented here considered a range of initial $e$ values and applied cell pressures, $\sigma_{\text {cell }}^{\prime}$, so that a CSL could be identified, enabling the data to be explored within the CSSM framework. For any drained triaxial compression test, the combination of stresses experienced by that particular sample during shearing (the stress path) will plot as a straight line on the $p^{\prime}-q$ plane with a gradient of 3:1, as shown in Figure 10(c). (This gradient can be derived by expressing $\sigma_{1}^{\prime}$ in Equation 2 in terms of $q$ and $\sigma_{\text {cell }}^{\prime}$ ). The schematics on Figure 10(c) indicate that the stress path for a sample such as A will approach the CSL monotonically. However, in the case of a dense sample, such as B, the stress path will extend beyond the CSL as the peak deviator stress is mobilized, returning to the CSL at large strains. Figure 11(a) presents the stress paths for the four tests completed in the current study. Using this approach to present the data, the CSL is taken as the locus of points that give the $p^{\prime}$ and $q$ values at the end of each tests, as shown in Figure 11(a). Just like sample B on Figure 10(c), the stress path for test $300 \mathrm{kPa}-549$ extends above the CSL, as it mobilizes its maximum deviator stress before it returns along the same linear path to end close to the CSL; this is a response that is typical for dense, dilative soils. ${ }^{[32,38,41]}$ The fact that a linear relationship between the end of tests points is observed here, indicates that this material conforms to our understanding of material behavior within the CSSM framework. The slope $(M)$ of the CSL plotted on the $p^{\prime}-q$ axes is directly related to $\phi_{\mathrm{cs}}^{\prime}$ as $\sin \left(\phi_{\mathrm{cs}}^{\prime}\right)=3 M /(6+M)$. The $M$ value for the tests described here is around $(M=0.8)$, reflecting the value of $\phi_{\mathrm{cs}}^{\prime}$ stated above. The ballotini samples in Reference 39 had $M=0.82$.

The responses observed during the triaxial tests are plotted in the mean effective stress-void ratio $\left(e-\log p^{\prime}\right)$ plane in Figure 11(b) using the semi-logarithmic axes typically employed in soil mechanics. The sample states at the end of the isotropic compression stage are indicated by the black circles in the figure. These points enable the compression behavior of the material to be described by the black line labeled "compression line" in Figure 11(b). Comparing this compression line with the typical behavior of soil during compression shown previously in Figure 10(b), e.g., ${ }^{42]}$ it can be seen that the pressures reached in these tests of semi-solid alloy (black curve in Figure 11(b)) do not reach the yield pressure of the material, when the material compression follows the straight normal compression line (NCL), rather the data agree well with the curved gray part of the compression curve in Figure 10(b).

The black points defining the compression line on Figure 11(b) also represent the sample condition at the start of the shearing stage during the test. The thin gray dotted lines on Figure 11b) describe the $e-p^{\prime}$ relationships during the shearing stage of the experiments. The data at the end of each test, when it is assumed that a critical state has been attained, are represented by the gray circles on Figure 11(b). These points lie approximately on a straight line (in the $e$-log p' plane) consistent with the concept of a Critical State Line and adhering to the CSSM framework presented in Figure 10. The CSL in Figure 11(b) lies to the left of NCL on this plane, 


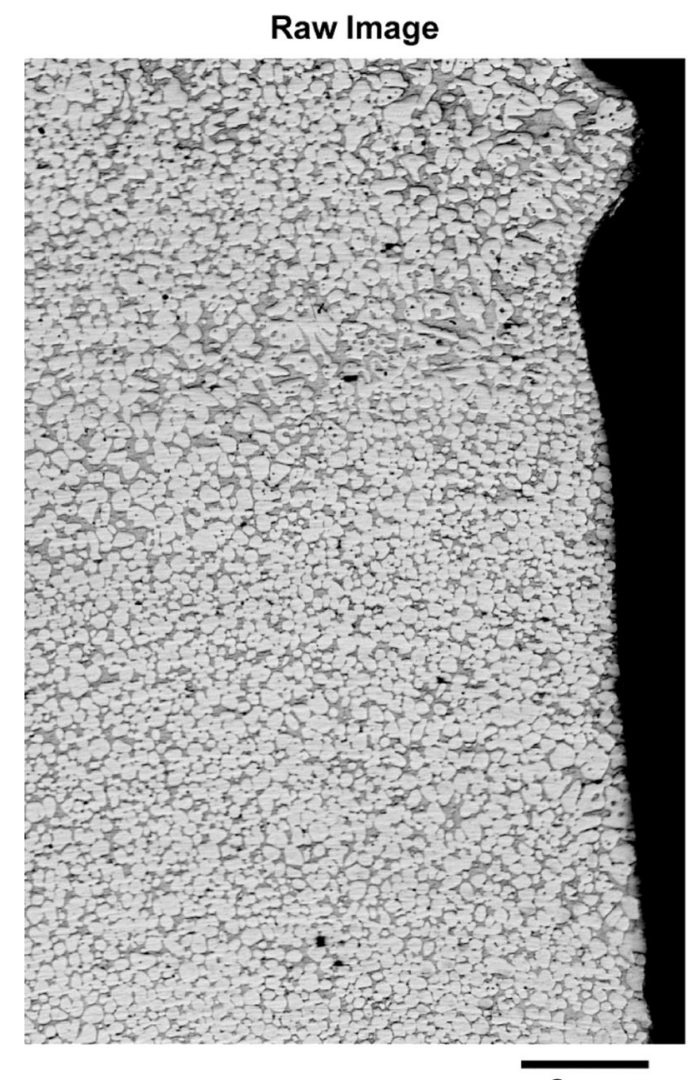

$2 \mathrm{~mm}$

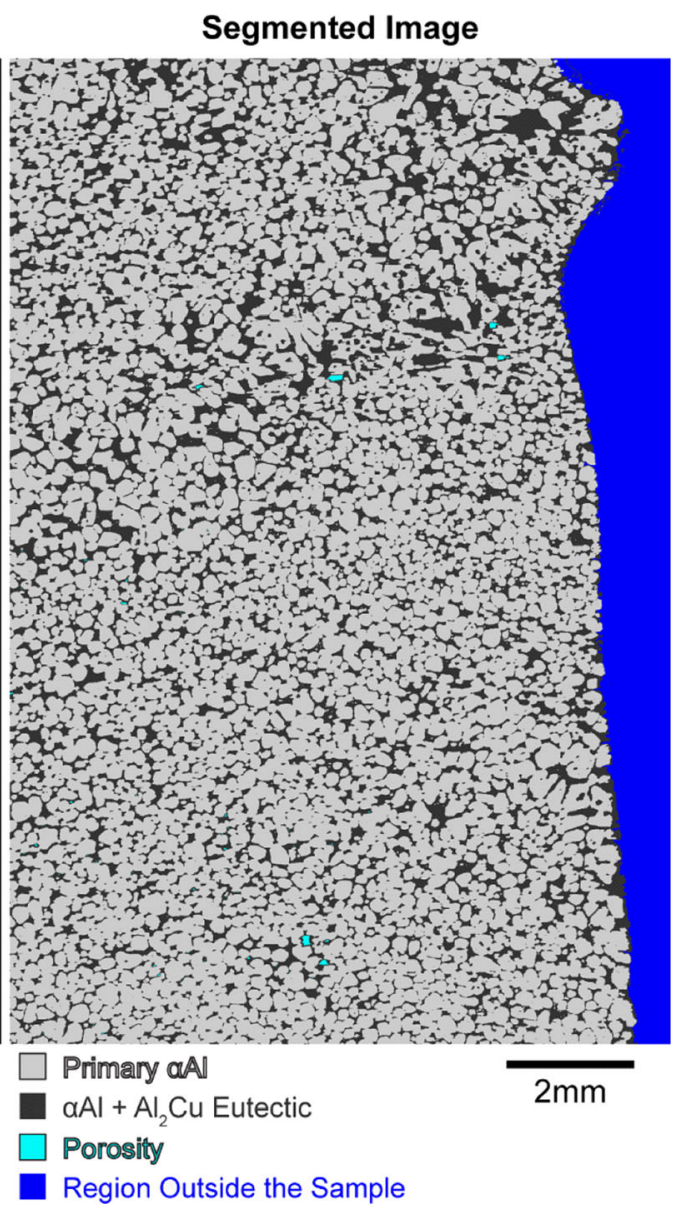

Fig. 8- Raw and segmented micrographs of the polished $300 \mathrm{kPa}-549{ }^{\circ} \mathrm{C}$ sample with a bulge and dilatant shear band.

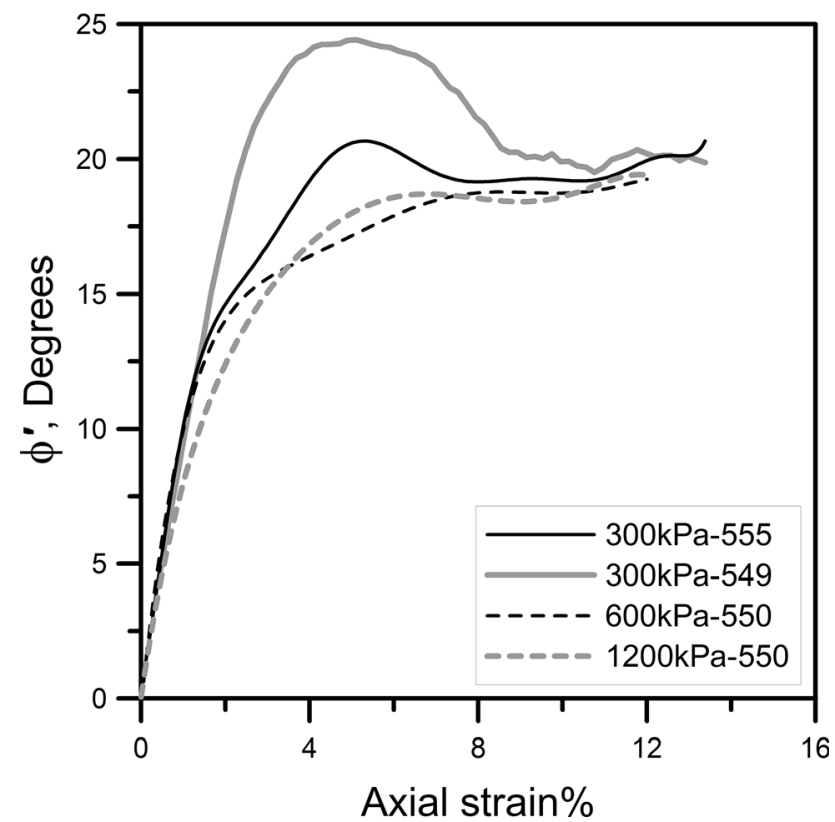

Fig. 9-Development of angle of internal shearing resistance during shearing stage. similar to Figure 10(b), again confirming that the material behavior conforms to the CSSM framework.

It can be seen from Figures 6, 9, and 11 that, for the globular semi-solid alloy at $\sim 70$ to 85 vol pet solid studied here, it is the combination of initial solid fraction, $g_{\mathrm{s}}$ (or void ratio, $e$ ) and initial mean effective pressure, $p^{\prime}$, that determine whether the material will undergo shear-induced dilation or contraction, and knowledge of the location of a sample relative to the CSL in $e: q: p^{\prime}$ space enables prediction of the response to shear. Samples whose initial state (i.e., following any compression state) is to the right of and above the CSL in the $e-\log p^{\prime}$ plane contract during shearing, experiencing a reduction in void ratio (increase in solid fraction) prior to reaching the CSL, as in samples 600 $\mathrm{kPa}-550$ and $1200 \mathrm{kPa}-550$ in Figure 11(b). On the other hand, samples whose initial state is on the left of and below the CSL will exhibit some dilation (decrease in solid fraction) and mobilize a peak stress during shearing before reaching their CSL as in the case of sample $300 \mathrm{kPa}-549$ in Figure 11(b). This is consistent with the CSSM framework developed for soils e.g., References 32,43-45.

The idea of applying soil mechanics theories to model the mushy zone has also been considered in the previous literature, ${ }^{[3,13,14,46]}$ for example by the use of Terzaghi's concept of effective stress ${ }^{[31]}$ and the application of some 


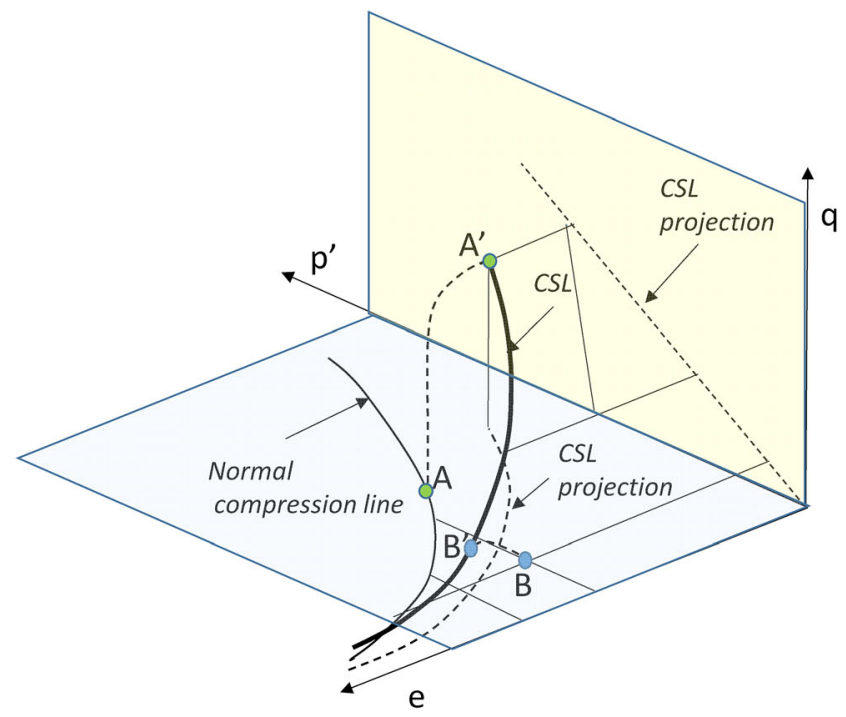

(a)

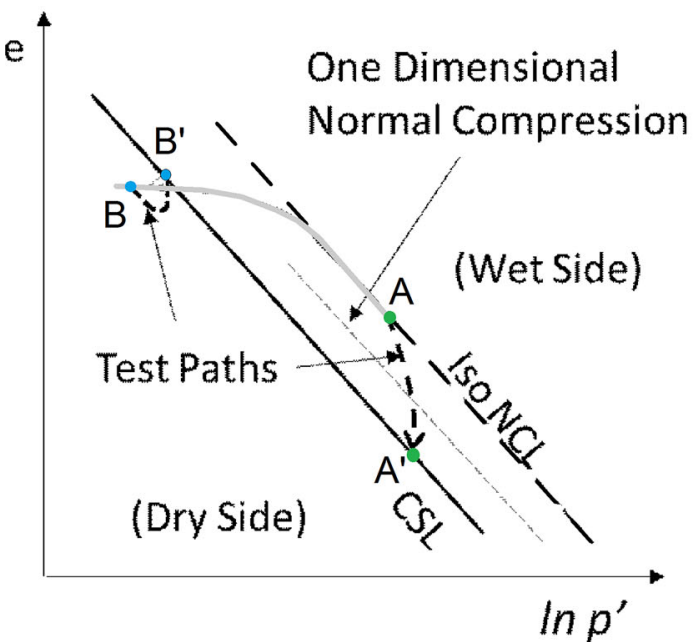

(b)

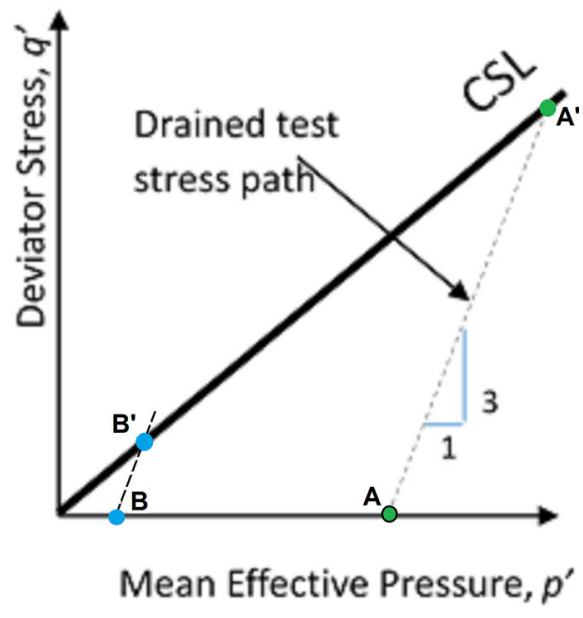

(c)

Fig. 10-Schematic diagram showing the critical state framework with two drained shearing test paths $(a)$ critical state line $(\mathrm{CSL})$ in $p^{\prime}, q$, $e$ space. (b) Projection of the CSL on the $e-\ln p^{\prime}$ plane, with the normal compression line (NCL). (c) Projection of CSL in $p^{\prime}-q$ plane.

laboratory testing procedures similar to those carried out on soils. ${ }^{[3,14,17,18,20,22,47]}$ Further to this, in the present work, it can be deduced that globular semi-solid alloys at $\sim 70$ to 85 pct solid have a pressure sensitivity similar to soils both in terms of the pressure-dependent flow stress, and also a pressure-dependent volumetric response, and the concept of a critical state locus in $e: q: p^{\prime}$ space seems to be both valid and useful for predicting the rheological response of semi-solid alloys, at least for the range of solid fraction and strain rate used.

While these experiments have shown the potential of interpreting and modeling semi-solid alloy deformation within a framework similar to CSSM, further features need to be added in future to generalize this framework for semi-solid alloys. For example, other microstructural parameters are needed in addition to the solid fraction (void ratio) such as the dendrite/grain envelope fraction and envelope shape, and the strain rate dependence of the CSL in semi-solid alloys needs to be considered. ${ }^{[46]}$ The framework also needs to link to/from suspension flow at lower solid fraction and to/from the viscoplastic deformation of a solid skeleton saturated with liquid at higher solid fraction. ${ }^{\text {[9] }}$

This work has shown the value of developing drained triaxial compression apparatus with a liquid reservoir capable of measuring both the in-flow and out-flow of interstitial liquid during the isothermal deformation of semi-solid alloys. While these experiments are significantly more complex than techniques such as parallel plate compression and direct shear that have been widely applied to semi-solid alloys previously, ${ }^{[1,11,21,22,24-27]}$ this approach enables the changing solid fraction (or void ratio), deviator stress, and the mean effective pressure to be known during compression and shearing (Figures 11(a) and (c)), which are the key 


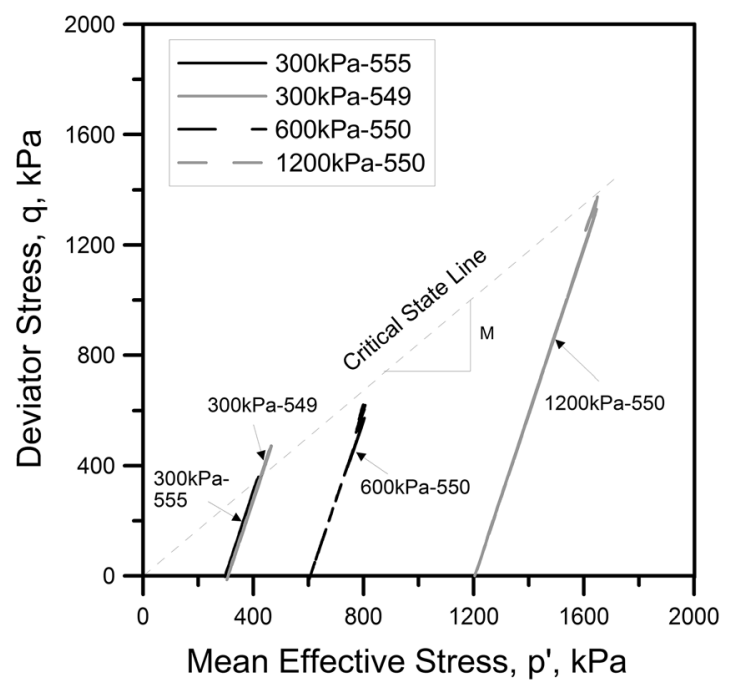

(a)

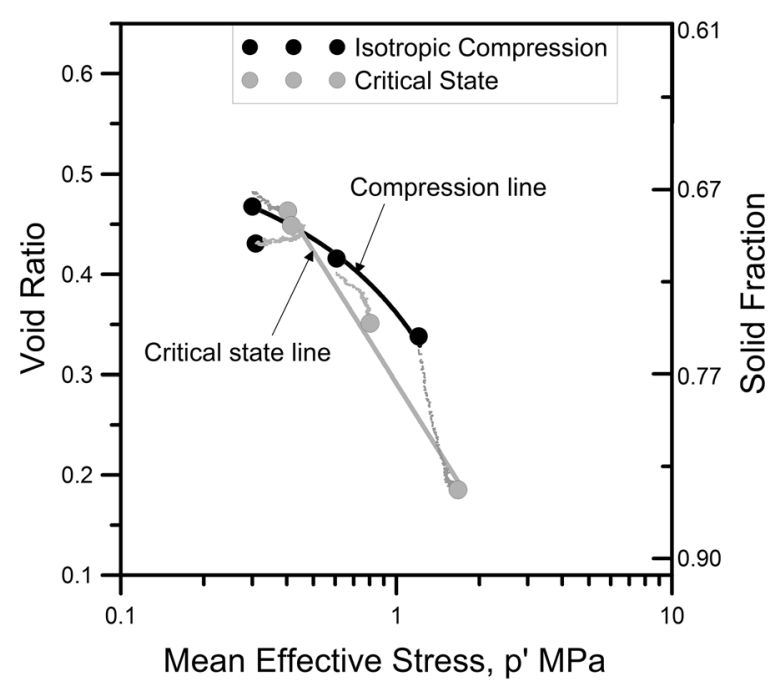

(b)

Fig. 11-(a) stress paths in deviator stress-mean effective pressure plane showing possible critical state line. (b) Sample packing state after compression stage (black filled circles) and the state at end of tests in $e-\ln p^{\prime}$ plane.

parameters in a critical state framework (Figure 9). Knowledge of the changing solid fraction during shearing is of additional importance for semi-solid alloys because, when liquid is expelled or drawn-in from a region of mush due to shear-induced contraction or dilation, it creates macrosegregation which affects the microstructure and properties of the casting, especially when strain localization occurs. Furthermore, knowledge of whether a local region will undergo shear-induced contraction or dilation provides knowledge of whether this form of deformation-induced macrosegregation will be negative or positive in this region. Such triaxial compression is likely to be relevant in, for example, the soft rolling reduction applied near the end of the sump in the continuous casting of steels, ${ }^{[48]}$ and in twin-roll casting of $\mathrm{Al}$ and $\mathrm{Mg}$ alloys. ${ }^{[49]}$

\section{CONCLUSIONS}

A new drained triaxial compression apparatus based on Bishop's triaxial apparatus used in mechanical testing of soil has been developed for semi-solid alloys. Drained triaxial compression experiments have been performed on globular semi-solid Al-15 wt pet $\mathrm{Cu}$ at 70 to 85 vol pet solid, with confining pressures from 300 to $1200 \mathrm{kPa}$. The results were then analyzed and compared with past work on soils in similar apparatus. The following conclusions can be drawn:

- Describing the pressure-dependent yielding behavior in terms of the Mohr-Coulomb model, all samples had an ultimate or critical state angle of shearing resistance, $\phi_{\mathrm{cs}}^{\prime} \approx 20^{\circ}$. This is lower than typical values for granular soils but is close to values obtained for tests on smooth glass ballotini and so is consistent with a semi-solid microstructure consisting of globules with smooth solid-liquid interfaces.

- The semi-solid samples all deformed with significant volumetric strains during shearing, where shear-induced contraction or shear-induced dilation occurred depending on the combination of solid fraction and confining pressure.

- Interpreting the triaxial data within the critical state soil mechanics (CSSM) framework, the semi-solid alloy had a pressure sensitivity similar to soils both in terms of the pressure-dependent flow stress, and also a pressure-dependent volumetric response. The concept of a critical state locus in $e: q: p^{\prime}$ space seems to be both valid and useful for predicting the rheological response of semi-solid alloys, at least for the range of solid fraction and strain rate used here.

- It is anticipated that a critical state soil mechanics (CSSM)-like framework could be applicable to semi-solid alloys after modifications to account for additional microstructural parameters and a strain rate dependence to the critical state locus (CSL).

\section{ACKNOWLEDGMENTS}

The authors would like to show their gratitude to the outstanding work and support of Mr. Neil Hughes during the research in the Earth Science Department at UCL. They also would like to express their appreciation to the valuable support of Dr. Sergey A. 
Belyakov from the Department of Materials at Imperial College London and Lang Yuan for his help in producing some of the DEM images in Figure 1. This project was funded via EPSRC Grants EP/K026763/1 and $\mathrm{EP} / \mathrm{K} 025724 / 1$.

\section{OPEN ACCESS}

This article is licensed under a Creative Commons Attribution 4.0 International License, which permits use, sharing, adaptation, distribution and reproduction in any medium or format, as long as you give appropriate credit to the original author(s) and the source, provide a link to the Creative Commons licence, and indicate if changes were made. The images or other third party material in this article are included in the article's Creative Commons licence, unless indicated otherwise in a credit line to the material. If material is not included in the article's Creative Commons licence and your intended use is not permitted by statutory regulation or exceeds the permitted use, you will need to obtain permission directly from the copyright holder. To view a copy of this licence, visit http://creat ivecommons.org/licenses/by/4.0/.

\section{APPENDIX A: NOTATION}

\section{Tensor quantities are in bold font}

$e$

$g_{\mathrm{s}}$

$p^{\prime}$

$q$

$\mathbf{u}$

$\delta_{y}, \delta_{x}$

$\gamma_{\mathrm{gb}}$

$\gamma_{\mathrm{s} 1}$

$\phi^{\prime}$

$\phi_{\mathrm{cs}}^{\prime}$

$\phi_{\text {peak }}^{\prime}$

$\boldsymbol{\sigma}_{\text {tot }}$

$\boldsymbol{\sigma}^{\prime}$

$\sigma_{\text {cell }}^{\prime}$
$\sigma_{1}^{\prime}, \sigma_{2}^{\prime}, \sigma_{3}^{\prime}$

$\sigma_{n}^{\prime}$

$\tau$
Void ratio, ratio of volume of voids to volume of solids

Solid volume fraction, ratio of volume of solid to total volume

Mean effective pressure or stress

Deviator stress

Interstitial liquid pressure or pore liquid pressure in soil mechanics

Displacement in $Y$ and $X$ direction

Interfacial energy of a grain boundary

Interfacial energy of a solid-liquid interface

Angle of shearing resistance

Ultimate, or critical state, angle of shearing resistance

Peak (maximum) angle of shearing resistance

Total stress

Effective stress

Effective cell pressure, confining pressure

Major, intermediate and minor effective stress

Normal effective stress

Shear stress

\section{SUPPLEMENTARY INFORMATION}

The online version of this article (doi:https://doi.org/ 10.1007/s11661-021-06213-9) contains supplementary material, which is available to authorized users.

\section{REFERENCES}

1. M. Suéry and M.C. Flemings: Metall. Trans. A, 1982, vol. 13A, pp. 1809-19.

2. C.L. Martin, D. Favier, and M. Suéry: Int. J. Plast., 1997, vol. 13, pp. 237-59.

3. O.D. Ludwig, C.L. Martin, and M. Suéry: MetallMater. Trans. A, 2005, vol. 36A, pp. 1525-35.

4. O. Reynolds: Philos. Mag., 1885, vol. 20, pp. 469-81.

5. C.M. Gourlay and A.K. Dahle: Nature, 2007, vol. 445, pp. 70-73.

6. C.M. Gourlay, C. O'Sullivan, J. Fonseca, L. Yuan, K.M. Kareh, T. Nagira, and H. Yasuda: JOM, 2014, vol. 66, pp. 1415-24.

7. B. Cai, S. Karagadde, L. Yuan, T.J. Marrow, T. Connolley, and P.D. Lee: Acta Mater., 2014, vol. 76, pp. 371-80.

8. K.M. Kareh, C. O'Sullivan, T. Nagira, H. Yasuda, and C.M. Gourlay: Acta Mater., 2017, vol. 125, pp. 187-95.

9. G. Laschet and H. Behnken: IOP Conf. Ser. Mater. Sci. Eng., 2019, vol. 529, p. 012083.

10. S. Vernède, P. Jarry, and M. Rappaz: Acta Mater., 2006, vol. 54, pp. 4023-34.

11. Y. Feng, M. Založnik, B.G. Thomas, and A.B. Phillion: Materialia, 2020, vol. 9, p. 100612.

12. C.M. Rodrigues, A. Ludwig, M. Wu, A. Kharicha, and A. Vakhrushev: Metall. Mater. Trans. B, 2019, vol. 50B, pp. $1344-50$.

13. A. Zavaliangos: Int. J. Mech. Sci., 1998, vol. 40, pp. 1029-41.

14. A.K. Dahle and L. Arnberg: Acta Mater., 1997, vol. 45, pp. $547-59$.

15. C.M. Gourlay, B. Meylan, and A.K. Dahle: Acta Mater., 2008, vol. 56 , pp. 3403-13.

16. S.M. Nabulsi: The behaviour of partially solidified aluminium-silicon alloys in a direct shear cell, Ph.D. Thesis: The University of Queensland, Australia, 1997.

17. T. Sumitomo, D.H. StJohn, and T. Steinberg: Mater. Sci. Eng. A, 2000, vol. 289, pp. 18-29.

18. C.L. Martin, S.B. Brown, D. Favier, M. Suéry: Mechanical beahvior of coarse dendrite semi-solid $\mathrm{Sn}-\mathrm{Pb}$ alloys under various stress states. In 3rd Int Conf. on Semi-solid processing of alloys \& composites, 1994, pp. 27-36.

19. T.G. Nguyen, D. Favier, and M. Suéry: Int. J. Plast., 1994, vol. 10, pp. 663-93.

20. T.G. Nguyen, M. Suery, D. Favier: Mechanical behaviour of semi-solid alloys under drained compression with lateral pressure. In Proceedings of the 2nd International Conference on semi-solid alloys and composites. Cambridge, MA, 1992.

21. S. Benke, S. Dziallach, G. Laschet, U. Prahl, and W. Bleck: Comput. Mater. Sci., 2009, vol. 45, pp. 633-37.

22. S.A. Metz and M.C. Flemings: AFS Trans., 1969, vol. 77, pp. $329-34$

23. J. Secondé and M. Suéry: J. Mater. Sci., 1984, vol. 19, pp. 3995-4006.

24. Z. Ma, H. Zhang, X. Zhang, X. Wu, H. Fu, L. Jia, and H. Zhang: J. Alloys Compd., 2019, vol. 803, pp. 1141-54.

25. A.B. Phillion, S.L. Cockcroft, and P.D. Lee: Acta Mater., 2008, vol. 56 , pp. $4328-38$.

26. M. Bellet, O. Cerri, M. Bobadilla, and Y. Chastel: Metall. Mater. Trans. A, 2009, vol. 40A, pp. 2705-17. 
27. S. Mihanyar, A. Mo, M. M'Hamdi, and K. Ellingsen: Metall. Mater. Trans. A, 2011, vol. 42A, pp. 1887-1895.

28. T.C. Su, C. O'Sullivan, H. Yasuda, and C.M. Gourlay: Acta Mater., 2020, vol. 191, pp. 24-42.

29. K.M. Kareh, P.D. Lee, R.C. Atwood, T. Connolley, and C.M. Gourlay: Nat. Commun., 2014, vol. 5, p. 4464, https:// doi.org/10.1038/ncomms5464.

30. A.W. Bishop and L.D. Wesley: Geotechnique, 1975, vol. 25, pp. $657-70$.

31. K. Terzaghi: Erdbaumechanik auf Bodenphysikalischer Grundlage, Franz Deuticke, Liepzig, 1925.

32. J.H. Atkinson and P.L. Bransby: The Mechanics of Soils: An Introduction to Critical State Soil Mechanics, McGraw-Hill, London, 1978.

33. S. Ganesan and D.R. Poirier: Metall. Trans. A, 1987, vol. 18A, pp. $721-23$.

34. I. Arganda-Carreras, V. Kaynig, C. Rueden, K.W. Eliceiri, J. Schindelin, A. Cardona, and H.S. Seung: Bioinformatics, 2017, vol. 33, pp. 2424-26.

35. J. Schindelin, I. Arganda-Carreras, E. Frise, V. Kaynig, M. Longair, T. Pietzsch, S. Preibisch, C. Rueden, S. Saalfeld, B. Schmid, J.Y. Tinevez, D.J. White, V. Hartenstein, K. Eliceiri, P. Tomancak, and A. Cardona: Nat. Methods, 2012, vol. 9, pp. 676-82.

36. K.H. Roscoe: Géotechnique, 1970, vol. 20, pp. 129-170.

37. J. Desrues and E. Andò: C R Phys., 2015, vol. 16, pp. 26-36.
38. R.F. Craig: Soil Mechanics, 5th ed., Chapman \& Hall, London, 1992.

39. I. Cavarretta, M. Coop, and C. O'Sullivan: Géotechnique, 2010, vol. 60 , pp. $413-23$.

40. K.H. Roscoe, A.N. Schofield, and C.P. Wroth: Géotechnique, 1958, vol. 8, pp. 22-53.

41. M.D. Bolton: Géotechnique, 1986, vol. 36, pp. 65-78.

42. M.R. Coop, I.K. Lee: The behaviour of granular soils at elevated stresses, Worth Memorial Symposium Thomas Telford, 1993, pp. 186-198.

43. W. Powrie: Soil Mechanics: Concepts and Applications, 2nd ed., Spon Press, Oxford, 2002.

44. R. Verdugo: Géotechnique, 1992, vol. 42, pp. 655-63.

45. K. Been and M.G. Jefferies: Géotechnique, 1985, vol. 35, pp. $99-112$.

46. T.C. Su, C. O'Sullivan, H. Yasuda, and C.M. Gourlay: Acta Mater., 2020, vol. 191, pp. 24-42.

47. B. Meylan, S. Terzi, C.M. Gourlay, and A.K. Dahle: Acta Mater., 2011, vol. 59, pp. 3091-101.

48. B.G. Thomas: Metall. Mater. Trans. B, 2002, vol. 33, pp. 795-812.

49. M.S. Kim, S.H. Kim, and H.W. Kim: Scripta Mater., 2018 , vol. 152 , pp. $69-73$.

Publisher's Note Springer Nature remains neutral with regard to jurisdictional claims in published maps and institutional affiliations. 